\title{
Kök Türkçe Yazitlarda Geçen Göller ve Nehirler
}

\author{
Lakes and Rivers in the Kök Turks İnscriptions
}

\section{Saadettin GÖMEÇ*}

\section{$\ddot{O} z$}

Eski Türk yurtlarında binlerce akarsu ve göl mevcut ise de bu incelemede Kök Türkçe metinlerde geçen otuzsekiz göl ve nehrin yerinin tespitine çalışılmış ve tarihi önemleri üzerinde kısaca durmaya özen gösterilmiştir. Bunun için de alfabetik bir sira takip edildi.

Anahtar Kelimeler: Türk Kitabeleri, Türk Gölleri, Türk Nehirleri

\section{Abstract}

As it is known, when the history is defined, the place element must also be considered. For this reason, historians focus not only on time but also on place and social results while they are talking about past events. The written sources in the language Kök Türks are the most precious Works of our history of Central Asia where a-thousands-year old Turkish history took place and still Turks live there. One can run across these Works in a wide area, beginning from China on the east, to the middle and North Europe on the west. Although there been thousands of rivers and lakes over the elder Turkish land. In this study, it was tried to find out the original place of the lakes and rivers that are mentioned at the inscriptions of the Kök Türk and Uygur period and their historical importance was taken into consideration in a short manner. For this reason an alphabetical order has been followed up.

Keywords: Turkish Inscriptions, Turkish Lakes, Turkish Rivers

*Prof. Dr. A.Ü. Dil ve Tarih-Coğrafya Fakültesi Tarih Bölümü. 
Bilindiği üzere tarihin tanımı yapılırken mekan mefhumu da göz önünde bulundurulur. Buna bağlı olarak tarihçiler, geçmişteki hadiselerden bahsederken sadece zamanı değil, mekanın ve sosyal sonuçların da üzerinde durur. Binlerce y1llık Türk tarihinin geçtiği ve bugün de halâ Türklerce meskun bulunan Orta Asya'daki tarihimizin hiç şüphesiz en kıymetli eserlerinin başında Kök Türkçe yazılı belgeler gelmektedir. Bunlara doğuda Çin'den başlayarak, batıda Avrupa'nın orta ve kuzeylerine kadar uzanan geniş bir coğrafyada rastlanılmaktadır ${ }^{1}$.

Söz konusu çalışmada özellikle Kök Türk ve Uygur çağına ait kitabelerde zikrolunan göller ve nehirlerin yerleriyle, tarihi önemleri üzerinde durmaya çalışacağız. Bunun için alfabetik bir sıra takip etmeyi düşünmekteyiz.

Eski Türkler göl için "köl" diyorlardı. Yani -k'li biçimi konuşulmaktaydı. Nehir veyahut da büyük akarsular içinse umumiyetle "ögüz” denmekteydi.

Ak Sub: Şine Usu Yazıtının daha önceki transkripsiyonlarında Kaşuy şeklinde kaydedilmişti, ancak biz bu adın "Ak Sub" biçiminde okunması gerektiğini düşünüyoruz. Moyun Çor'un kardeşi Tay Bilge Tutuk ile yaptığı mücadeleler sırasında geçen ${ }^{2}$ Ak Sub, herhalde Ubsu Göl'ün kuzey taraflarında olmalıdır. Bugün Ka-kem'in güney kollarından birisi Aksu adını taşımaktadır ${ }^{3}$. Bununla birlikte iki kardeşin savaşlarının Selenge civarlarında gerçekleştiğini yazıttan öğrenmekteyiz ki, burası Selenge'nin kuzey-batı taraflarıdır. Moyun Çor, Tay Bilge Tutuk'u Ak Sub'u dolanarak, Çıgıltır Köl'te kuşatmıştır". Bilindiği gibi bu mücadelelerden Moyun Çor galip çıkacak ve Uygur Kaganlığının başına geçecektir.

Ak Termel: Kök Türk tarihine baktığımızda, 710 senesinde kaganlık ordularının Kırgızlar üzerine büyük bir seferi söz konusudur. Çin, On Ok ve Kırgızlar, Kök Türklere düşman olunca büyük devlet adamı Tunyukuk, gece ve gündüz düşünmüş, bir savaş planı hazırlayarak, ilk önce Kırgızlara vurmanın doğru olacağına karar vermiştir. Kırgızlara ulaşmak için Kögmen Dağlarının geçilmesi gerekmektedir. Ancak kar yüzünden bütün yollar kapanmıştır. Fakat, Az topraklarından doğru oraya gitmenin mümkün olduğu öğrenilmiş ve Anı Suyu boyunca ilerlenmiştir. Zorlu bir uğraştan sonra Ak

\footnotetext{
${ }^{1}$ Hatta biz öyle sanıyoruz ki eski İskandinav ve Germen yazılarının menşei de Türk alfabesiyle ilişkilidir.

${ }^{2}$ Bakınız, Şine Usu Yazıtı, Doğu tarafı, 6. satır: Sekizinç ay eki yangıka Çıgıltır Költe, Aksub kezü süngüşdim.

${ }^{3}$ Biz daha önce yaptığımız bir çalışmada, Ak Sub’u bugünkü Doğu Türkistan'daki Tarım Nehri'nin kolu olan Aksu ile birleştirmiş isek de, daha sonraki incelemelerimize göre bunun mümkün olamayacağını gördük. Bakınız, S.Gömeç, "Kök Türkçe Yazıtlarda Geçen Yer Adları", Türk Kültürüi, 34/453, Ankara 2001, s.25-26.

${ }^{4}$ S.Gömeç, Uygur Türkleri Tarihi ve Kültüirü, 2. baskı, Ankara 2000, s.27.
} 
Termel geçilmiş, ancak orduya yol gösteren klavuz yolu şaşırdığ 1 için cezalandırılmış, kaganın emri üzerine askerin daha hızlı hareket etmesi için buyruk verilmiştir ${ }^{5}$. Bu harekatın sonucunda Kırgızlar ani bir baskına uğramışlar, büyük bir kısmı öldüğü gibi onların kaganları da ortadan kaldırılmıştır ${ }^{6}$.

Kırgız savaşları sırasında geçen Ak Termel, Anı Suyu'na yakın, Yenisey'in kollarından birisi olsa gerek. Bugün de Anı Nehrinin yukarılarına varmak için $A k$ Sug veya sadece $A k$ denilen bir sudan geçildiği söylenmektedir ${ }^{7}$.

Anı Sub: 710 sıralarında Çin'in On Oklar ve Kırgızların Kök Türklere düşman olmaları sebebiyle yukarıda verdiğimiz metinde olduğu gibi Anı Suyu adıyla karşılaşıyoruz ${ }^{8}$. Bu sefer hususunda Tunyukuk Yazıtında; Kırgızlara giderken kar yüzünden bütün yolların kapandığı, fakat $\mathrm{Az}$ ülkesinden doğru oraya gitmenin mümkün olduğu anlaşılmış ve Anı Suyu boyunca ilerlenmişti ${ }^{9}$. Burada söz konusu olan Anı, Yenisey'in kollarından biri olan Abakan'ın bir parçasıdır ${ }^{10}$.

Arkar Başı: Şine Usu Yazıtının güney tarafı, 1. satırında Kem, Kargu ve İrtiş Nehrinden sonra geçer. Buna göre Arkar Başı İrtiş Nehrine akan suların başlarından biridir ${ }^{11} .752$ senesinde Uygurlara karşı bir Tokuz OguzKırgız ittifakı söz konusudur. Şine Usu Yazıtından anlaşılacağına göre Kırgızlara bağlı olan Çikler de bu ittifak arasına alınmış ve Uygurlara bir darbe vurma hazırlığına girişilmişti ${ }^{12}$. Daha sonra bu birleşmeye Üç Karluk boyu da katıldı. Bunların hareketini önceden haber alan Uygurlar, evvela Üç Karluklara, arkasından da Çiklere boyun eğdirip; Çikler üzerine bir tutuk ile 1şbara ve tarkanlar gönderdiler ${ }^{13}$.

\footnotetext{
${ }^{5}$ Bakınız, Tunyukuk Yazıtı, I. Taş, Doğu tarafı, 6-7; Kuzey tarafı 1-2. satırlar: Kögmen yolı bir ermiş tumış tiyin işidip "bu yolın yorısar yaramaçı" tidim yirçi tiledim Çöllüg iz eri bultım işitdim: "Az bir yolı Anı birle...bir at orukı ermiş anın barmış nngar aytıp bir atlıg barmış" tiyin "ol yolın yorısar anç" tidim sakıntım kaganıma ötüntim sü yorıtdım "at altın" tidim Ak Termel keçe ogurkalatdım.

${ }^{6}$ S.Gömeç, Kök Türk Tarihi, 2. baskı, Ankara 1999, s.56-58.

${ }^{7}$ L.P.Potapov, "O Narode Bökliyskoy Stepi”, Tyurkologiçeskiye Issledovaniya, MoskovaLeningrad 1963, s.290-291; Gömeç, a.g.m., s.26.

${ }^{8}$ Gömeç, a.g.e., s.56-57.

${ }^{9}$ Bakınız, Tunyukuk Yazıtı, I. Taş, Doğu tarafı, 6-7; Ança sakıntım: “ilk Kırkızka süleser yig ermiş" tidim Kögmen yolı bir ermiş tumış tiyin işidip "bu yolın yorısar yaramaçı" tidim yirçi tiledim Çöllüg iz eri bultım. işitdim: "Az bir yolı Anı birle...bir at orukı ermiş".

${ }^{10}$ Gömeç, a.g.e., s.57.

${ }^{11}$ Gömeç, a.g.m., s.27.

${ }^{12}$ Bakınız, Şine Usu Yazıtı, Güney tarafı, 1. satır:...sü Karluk tapa...Kem Kargu...İrtiş Ögüzig Arkar Başı...anta er kamış...yanta sallap keçdim bir yegirminç ay sekiz yegirmike...yolukdım...

${ }^{13}$ Gömeç, Uygur Türkleri..., s.31.
} 
Balıklıg: $\mathrm{Bu}$ nehrin adını da yine 752 yılı olayları vesilesiyle görmekteyiz. Yukarıda da belirttiğimiz üzere Uygurlar Kırgız, Karluk ve Çiklerin muhalefetiyle karşılaşmışlardı. Bu sırada Çin'deki Oguzlar ve Türkler de onlara karşı harekete geçtiler. Uygur ordusu üç bin kişiydi. Ancak onlar hasımlarını yenmeyi başardılar. Daha sonra da Orkun ve Balıklı nehrinin kavşağında Moyun Çor otağını kurdurdu. Yenisey kıyılarında muhtemelen Abakan civarlarında Çigillere de bir darbe vuruldu ${ }^{14}$. Şine Usu Yazıtında anlatılan bu bilgilere baktığımızda, Balıklıg'ın Orkun'un kollarından birisi, muhtemelen de bu büyük ırmağın orta taraflarında bir yer olduğu anlaşılmaktadır ${ }^{15}$.

Bolçu: Hem bir nehir adı olup, büyük bir ihtimalle İrtiş'in kollarından birisidir, hem de başka bir coğrafi mevki olması mümkündür. Onu Urungu Nehriyle birleştirenler de vardır ${ }^{16}$. Bolçu adını dört büyük kitabede görmekteyiz ${ }^{17}$. 8. asrın başlarında Çin imparatorluğunun oyunlarına gelen On Oklardan Türgişler, Kırgızlar ve onların akrabaları Çikler, Kök Türk Kaganlığına cephe almışlardı. Büyük devlet adamı Tunyukuk gece uyumayıp, gündüz oturmayıp, bütün bu düşmanlarını birer birer tesirsiz hale getirdi. Kitabelerde en son olarak da Türgişlerle olan savaştan söz edilmektedir ${ }^{18}$. Köl Tigin ve Bilge Kagan yazıtlarında; Altun Yış aşılarak ve İtiş Nehri geçilerek, tıpkı Kırgızlara olduğu gibi Türgişlere de ani bir baskın yapıldı. Türgiş kaganının ordusu Bolçu'da Kök Türklerin üzerine saldırdıysa da Köl Tigin burada da kahramanlığını gösterdi ve Türgiş kaganının bakanlarından Az Tutuk'u bizzat kendisi ele geçirdi. Onların başında bulunan kagan So-ko ${ }^{19}$ ailesi ile birlikte öldürüldü ve böylece Türgiş halkına boyun eğdirildi ${ }^{20}$ deniliyor. 300 bine yakın ordusu olduğu söylenen So-ko'ya

\footnotetext{
${ }^{14}$ Bakınız, Şine Usu Yazıtı, Güney tarafı, 8-10. satırlar:...Tabgaçdakı Oguz-Türk taşıkmış anta katılmış anta beyler...biş yüz kedimlig yadag bi eki şaşıp kelti küngim kulım bodunıg tengri yer anta ayu birti anta sançdım...Karluk tapa tezip kirti anta yana tüşip Orkun Balıklıg beltirinte el örginin anta örgipen ititdim...

${ }^{15}$ S.Gömeç, "Şine-Usu Yazıtı'nda Geçen Yer Adları Üzerine”, Belleten, LXIV/240, Ankara 2001, s.433.

${ }^{16}$ Bolçu'nun, bugünkü Bolun Tokoy kasabası olduğu da söylenmektedir. Bakınız, R.Giraud, L'Empire des Turcs Celestes, Paris 1960, s.178-179; L.N.Gumilev, Hazar Çevresinde Bin Yıl, Çev. A.Batur, İstanbul 2001, s.165.

${ }^{17}$ Bakınız, Köl Tigin Yazıtı, Doğu tarafı, 37. satır; Bilge Kagan Yazıtı, Doğu tarafı, 28. satır; Tunyukuk Yazıtı, I. Taş, Kuzey tarafı, 35. satır; Şine Usu Yazıtı, Güney tarafı, 1-2. satır.

${ }^{18}$ Gömeç, Kök Türk Tarihi, s.56-58.

19 Sou-ko (veya So-ko) adını biz, Türgiş boyu So-ko ile alâkalı görmekteyiz. Bunun da muhtemelen Saka ile irtibatı olabilir! Türgiş beyi So-ko (Saka) kendisini kagan ilan ettikten sonra, bugünkü Doğu Türkistan'da Kuça, Aksu ve Kaşgar gibi bazı yerlere akınlar düzenlemişti.

${ }^{20}$ Bakınız, Köl Tigin Yazıtı, Doğu tarafı, 36-38. satırlar; Bilge Kagan Yazıtı, Doğu tarafı,
} 
(belki Saka) karşı aslında burada bir talihsizlik ya da ihanet söz konusudur. Kardeşi Börü, kendisine yönetimde fazla yetki verilmediğinden ve kendi halkının sayıca az olmasından dolayı Kapgan Kagan'ın tarafına geçmişti. Kök Türk ordularına rehberlik eden Börü, kardeşi So-ko'nun hakimiyeti altındaki Tanrı Dağları'nın kuzeyi, Tarbagatay Dağları ve İli Vadisi'nin yeniden merkezi idareye sokulmasina vesile oldu. Fakat Kapgan Kagan, Soko'nun kardeşi Börü' yü de ileride tehlike yaratabileceğini düşünerek ortadan kaldırdı ${ }^{21}$. İşin gerçeği ağabeyine ihanet eden bir kardeş, kendisine de rahat rahat karş1 gelebilirdi. Kapgan bu durumu göz önünde bulundurmuştur.

Köl Tigin ve Bilge Kagan yazıtlarında özet şeklinde verilen Türgiş savaşı, Tunyukuk Yazıtında aynen Kırgız seferinde olduğu gibi savaştan önceki ve sonraki olaylar da dahil olmak üzere teferruatlı olarak anlatılmıştır. Tunyukuk; Altun Yış ve İrtiş Ögüz'ün büyük zorluklardan sonra geçildiğini, Kök Türk ordusunun Bolçu'ya tan ağarırken ulaştığını, keşif kollarının Türgiş ordusunun Yarış Yazısı'nda toplandığını haber verdiğini, burada biriken Türgiş kuvvetlerinin 100.000 olduğunu, söylemektedir ${ }^{22}$.

Burgu: Şine Usu Yazıtında, ünlü Moyun Çor'un ağabeyi Tay Bilge Tutuk ile yaptığı savaşlar sebebiyle anılıyor. Moyun Çor birçok çağırılar yapmış olmasına rağmen kardeşi ve yandaşlarını ikna edememiş ve Burgu'da, haziran ayının 15. günü bir muharebeye daha girdikten sonra önemli miktarda insan ve hayvan ele geçirip, Selenge'nin batısındaki (veya gerisindeki) Yılan Kol'dan güney taraftaki Şıp Başı'na kadar asker çıkarmışıır' ${ }^{23}$. Terhin Yazıtında da Moyun Çor'un gezip-dolaştığı sular arasındadır $^{24}$. Yukarıda adı geçen Burgu'nun Ka Kem olduğu iddia

27-28. satırlar: Ol yılka Türgiş tapa Altun Yışıg toga İrtiş Ögüzig keçe yorıdımız Türgiş bodunıg uda basdımız Türgiş kagan süsi Bolçuda otça borça kelti süngüşdümiz Köl Tigin başgu boz at binip tegdi başgu boz at (anta ölti)...ikisin özi altuzdı anta yana kirip Türgiş kagan buyrukı Az Tutukıg eligin tuttı kaganın anta ölürtümiz ilin altımız Kara Türgiş bodun kop içikdi.

${ }^{21}$ Bakınız, J.M.Deguignes, Hunların, Türklerin, Moğolların ve daha sair Tatarların Tarih-î Umumisi, C. II, İstanbul 1924, s.469-472; E.Chavannes, Documents sur les TouKiue [Turcs] Occidentaux, Petersburg 1903, s.77-78; E.Baytur, Şincan'daki Milletlerin Tarihi, Pekin 1991, s.363; Gömeç, a.g.e., s.56-60.

${ }^{22}$ Bakınız, Tunyukuk Yazıtı, I. Taş, Kuzey tarafı, 11; II. Taş, Batı tarafı, 1. satır: Altun Yışıg yolsuzın aşdımız İrtiş Ögüzig keçigsizin keçdimiz tün katdımız Bolçuka tang öntürü tegdimiz tılıg kelürti sabı antag: "Yarış Yazıda on tümen sü terilti" tir.

${ }^{23}$ Bakınız, Şine Usu Yazıtı, Doğu tarafı, 2-3. satırlar: Kentü bodunım" tidim "udu keling" tidim kodup bardım kelmedi yiçe ertim Burguda yetdim törtünç ay tokuz yangıka süngüşdim sançdım anta yılkısın barımın kızın-koduzın kelürtim bişinç ay udu kelti Sekiz Oguz, Tokuz Tatar kalmatı kelti Selenge kidin Yılan Kol birdin sıngar Şıp Başınga tegi çerig itdim.

${ }^{24}$ Bakınız, Terhin Yazıtı, Batı tarafı, 4. satır: Sekiz Selenge, Orkun, Togla, Sebintürdü, Kargu ve Burguda sularımda konar göçerdim ben. 
edilmişse $^{25}$ de, bize göre Ka Kem uzakta kalmaktadır. Çünkü Terhin Yazıtında Sekiz Selenge, Orkun, Togla, Sebintürdü ve Kargu'dan sonra adı geçiyor ki, dolayısıyla bu akarsulara yakın bir nehir olmalıdır.

Çıgıltır Köl: Şine Usu Yazıtının doğu tarafı, 6. satırında, sekizinci ayda Selenge Irmağının kaynakları bölgesinde olduğunu düşündüğümüz Çıgıltır Kölde, Ak Sub (Aksu) dolanılarak, Moyun Çor'un kardeşiyle bir muharebeye daha girdiğini ve ayın onbeşinde Keyre Başı ve Üçbürkü'de Tay Bilge Tutuk tarafını tutan Tatarlarla kıyasıya bir savaş yaptığını ve onları takip ettiğini görüyoruz ${ }^{26}$. Çıgıltır Köl'ün adı bize göre Anadolu'da Çıldır Gölü'nde yaşamaktadır. Söz konusu iki kardeşin bu savaşları da herhalde 748-749 tarihlerinde meydana gelmiştir ${ }^{27}$.

Çuş Başı: Meşhur Kök Türk hükümdarı Kapgan Kagan'ın son zamanlarına doğru büyük bir Oguz isyanı çıktı ${ }^{28}$. Köl Tigin Yazıtında, Oguzların kendi halkı olduğu, yer ile gök birbirine karıştığı için onların düşmanlık yaptıkları, Oguzlarla bir yılda tam beş defa savaşıldı ${ }^{29}{ }^{29}$, haber verildiği halde; Bilge Kagan kitabesinde de Tokuz Oguzların kendi bodunları olduğu, yine gök ile yerin birbirine karıştığı ve Oguzların içine kıskançlık düştüğü için düşman oldukları, ancak bir yılda dört defa savaşıldığ $^{30}$ anlatılmıştır. İşte bu Oguzlarla yapılan üçüncü savaşın mevkiidir. Türk milletinin burada gevşekliğinden de söz açılıyor. Ölecek olanların yeniden dirildiği ve Tongra Yılpagut'un bir oymağının Tonga Tigin'in cenaze töreninde kuşatılarak hırpalandığ ${ }^{31}$ haberi veriliyor. Burasının Togla Nehri civarlarında bulunduğunu sanmaktayız.

İrlün: Yerini tam olarak belirleyemediğimiz, ancak Cungarya bölgesinde bir yer olduğunu sandığımız İrlün ${ }^{32}, 752$ tarihinde Basmıl ve Karluklarla olan savaş vesilesiyle Şine Usu Yazıtında geçer. Uygur kaganı Moyun Çor, Oguzların onlar hakkındaki planlarını bir casus vasıtasıyla

\footnotetext{
${ }^{25}$ S.G.Klyaştornıy, "Terhinskaya Nadpis", Sovyetskaya Tyurkologiya, No 3, Bakû 1980, s.94.

${ }^{26}$ Bakınız, Şine Usu Yazıtı, Doğu tarafı, 6: Sekizinç ay eki yangıka Çıgıltır Költe Aksuy kezü süngüşdim anta sançdım anta udı yorıdım ol ay biş yegirmike Keyre Başı Üçbirküde (üç-bireki) Tatar birle katı tokıdım sıngarı bodun içikdi.

${ }^{27}$ Gömeç, Uygur Türkleri..., s.26-27.

${ }^{28}$ Gömeç, Kök Türk Tarihi, s.63-65.

${ }^{29}$ Bakınız, Köl Tigin Yazıtı, Kuzey tarafı, 4. satır: Tokuz Oguz bodun kentü bodunım erti tengri yir bulgakın üçün yagı boltı bir yılka biş yolı süngüşdümiz.

${ }^{30}$ Bakınız, Bilge Kagan Yazıtı, Doğu tarafı, 29-30. satırlar: Tokuz Oguz mening bodunım erti tengri yir bulgakın üçün yagı bolt. bir yılka tört yolı süngüşdümiz.

${ }^{31}$ Bakınız, Köl Tigin Yazıtı, Kuzey tarafı, 7. satır; Bilge Kagan Yazıtı, Doğu tarafı, 30-31. satırlar: Üçünç Çuş Başınta süngüşdim Türk bodun adak kamşatdı yablak boltaçı erti oza yanya keligme süsin agıtdım öküş ölteçi anta tirilti anta Tongra Yılpagutı bir oguşıg Tonga Tigin yogınta egire tokıdım.

${ }^{32}$ Gömeç, Uygur Türkleri..., s.33.
} 
öğrenir. $\mathrm{Bu}$ arada Basmıllar da düşman olurlar. Fakat Uygurlar bu rakiplerine fırsat vermeyip, bozguna uğrattılar. Ondan sonra Karlukların malını-mülkünü yağmaladılar. Basmıllar ve Karlukların yurdu talan edildikten sonra Yogarı Yarış'da ${ }^{33}$ bir kez daha yendiler. İrlün'de ve Talakamın'da $^{34}$ düşmanlara yetişildi. Bu sırada Çin'deki Türkler de Uygurlara karşı harekete geçmişlerdi. Uygur ordusu üç bin kişiydi. Ancak Uygurlar hasımlarını alt etmeyi başardılar ${ }^{35}$.

İrtiş: Bilindiği üzere Asya'nın ve dünyanın önemli nehirleri arasındadır. $2970 \mathrm{~km}$ uzunluğundaki bu ırmağın kaynakları Altaylardan başlar. Malum olduğu üzere bu irmak, Kimek destanlarının da ana unsurlarından birisidir. Altun Orda Hanlığının kurucusu sayılan Cuci'nin mezarının dahi bu ırmağın kıyısında olduğuna inanılıyor ki, bilindiği üzere Çingiz Han ülkesini çocukları arasında paylaştırırken, Cuci'ye bu bölge düşmüştï ${ }^{36}$.

Evvelce de söz ettiğimiz üzere 710 sıralarında Kök Türk ordularının İtiş Nehri civarlarında yaşayan Türgişlerle bir mücadelesi vardır ${ }^{37}$. Köl Tigin ve Bilge Kagan yazıtlarında özet şeklinde verilen Türgiş savaşı ${ }^{38}$, Tunyukuk Yazıtında aynen Kırgız seferinde olduğu gibi savaştan önceki ve sonraki olaylar da dahil olmak üzere teferruatlı olarak anlatılmıştır. Buna göre; "Altun Yış ve İrtiş Ögüz büyük zorluklardan sonra geçildi. Kök Türk ordusu Bolçu' ya tan ağarırken ulaştı. Keşif kolları, Türgiş ordusunun Yarış

\footnotetext{
${ }^{33}$ Yarış Yazısının bir bölümü olup, burası Cungarya bölgesinde olmalıdır.

${ }^{34}$ İrlün için geçerli olan mesele bunun için de söz konusudur.

${ }^{35}$ Bakınız, Şine Usu Yazıtı, Doğu tarafı, 12. satır; Güney, 1-9. satırlar: ...tokuz yangıka sü yorıtdım...tutuk başın Çik tapa bınga ıtdım İsi Yer tapa az er ıtdım kör tidim Kırkız kanı Kögmen irinte eb barkında ermiş yelmesin İsi Yeringerü 1 dmış yelmesin mening er anta basmış til tutmış kanınga İsinge er kelti Karluk İsinge kelmedük tidi...sü Karluk tapa...Kem Kargu...İrtiş Ögüzig Arkar Başı...anta er kamış...yanta sallap keçdim bir yegirminç ay sekiz yegirmike...yolukdım Bolçu Ögüzde Üç Karlukıg anta tokıdım anta yana tüşdim Çik bodunıg bıngam süre kelti...çıtımın yayladım yaka anta yaladım Çik bodunka tutuk birtim 1şbaras tarkat anta ançuladım...Kazluk Költe...Taygun Költe tiriltim bidgüçi er anta ıtdım er kelti Kara Yotulkan keçip kelirti ben utru yorıdım...Karluk tapa er ıdmış...içre ben bulgayın timiş taşdından...Basmıl yagıdıp ebimrü bardı anı içgermedim taşdından Üç Karluk üç ıduk...bişinç ay altı otuzka süngüşdim anta sançdım...toguru sançdım anta ötrü Türgiş Karlukıg tabarın alıp ebin yulıp barmış ebime tüşmiş....sekizinç ay ben udu yorıdım ebimin Ersegünte Yula Költe kotım anta irtim...Yogarı Yarışda süsin anta sançdım ebi on kün öngre ürküp barmış anta yana yorıp tüşdim...İrlünte Talakamınta yetdim...Tabgaçdakı Oguz Türk taşıkmış anta katılmış anta beyler...biş yüz kedimlig yadag bir eki şaşıp kelti küngim kulım bodunıg tengri yer anta ayu birti anta sançdım

${ }^{36}$ S.Gömeç, Türk Kültürünün Ana Hatları, Ankara 2006, s.15.

${ }^{37}$ Gömeç, Kök Türk Tarihi, s.58.

${ }^{38}$ Bakınız, Köl Tigin Yazıtı, Doğu tarafı, 36-38. satırlar; Bilge Kagan Yazıtı, Doğu tarafı, 27-28. satırlar.
} 
Yazı' da ${ }^{39}$ toplandığı haberini verdiler. Burada biriken Türgiş kuvvetlerinin sayısının 100.000 olduğu bildirilmektedir. Kök Türk ileri gelenlerinden bazıları düşmanla karşılaşılmadan geri dönülmesini istemişler; fakat Tunyukuk birçok zorluklara rağmen Altun Yış ve İrtiş Ögüz'ün aşıldığını, Tanrı, Umay ${ }^{40}$ ve kutlu vatanın onların yanında olduğunu, düşmanlarının çokluğundan korkulmaması gerektiğini söylemiş ve saldıralım demiştir. Neticede Kök Türk ordusu taarruza geçti ve Türgiş kuvvetlerini savaşın birinci gününde mağlubiyete uğrattılar. İkinci gün Türgiş askeri yeniden toparlanmış ve hücuma kalkmışsa da Tunyukuk ile Bilge arasında sıkıştırılan On Oklar dağıtılmışlardı. Bu savaş sonucunda yukarıda da zikrettiğimiz gibi Türgiş kaganı, yabgusu ve şadı öldürüldü. Daha sonra devletin temelini oluşturan On Ok halkına haber gönderilerek, yeniden devlete boyun eğmeleri sağlandı"41. Köl Tigin ve Bilge Kagan yazıtlarında Türgiş seferinin kısaca anlatılmasının sebebi bu savaşta ordu komutanın İni İl Kagan olmasından ileri geldiğini sanıyoruz. Köl Tigin ve Bilge Kagan kitabelerinde kendilerine rakip olarak gördükleri İni İl Kagan'ın faaliyetlerine pek değinilmez ${ }^{42}$.

Bundan başka İrtiş Nehrinin adı Şine Usu Yazıtında da karşımıza çıkmaktadır. Yazıtın güney tarafı, 1. satırda geçen Kem'den sonra Kargu'yu, daha sonra İrtiş Nehri'ni, nihayet Arkar Başı coğrafî adlarını görüyoruz. Bu yine Oguz, Kırgız, Karluk, Çik, Basmıl gibi Türk boylarının Uygurlara karşı 752 tarihinde yaptıkları ittifak sebebiyledir ${ }^{43}$.

\footnotetext{
${ }^{39}$ Yarış Yazı, Tarbagatay ve Tanrı Dağları arasındaki Cungarya Ovası'dır. Bakınız, Gömeç, Kök Türk Tarihi, s.58.

${ }^{40}$ Yaptığımız araştırmalar neticesinde, Umay'ın ya milattan önceki devirlerde yaşamış kahraman bir Türk kadını veya bir melek olduğu kanaatine varmış bulunuyoruz. Belki de Türk destanlarındaki dişi kurtun kendisidir. Bakınız, S.Gömeç, "Umay Meselesi”, Türk Kültürü, Sayı 318, Ankara 1989, s.630-634; S.Gömeç, "Drevnyaya Religiya Tyurok", Şamanizm Kak Religiya: Genezis, Rekonstruktsiya, Traditsii. Tezisı Dokladov Mejdunarodnoy Nauçnoy Konferentsii, 15-22 avgusta 1992 g. Yakutsk 1992.

${ }^{41}$ Bakınız, Tunyukuk Yazıtı, I. Taş, Kuzey tarafı, 11. satır; II. Taş, Batı tarafı, 1-8. satırlar: Altun Yışıg yolsuzın aşdımız İrtiş Ögüzig keçigsizin keçdimiz tün katdımız Bolçuka tang öntürü tegdimiz tılıg kelürti sabı antag: "Yarış Yazıda on tümen sü terilti" tir ol sabıg işidip; "beyler kopın yanalım arıg ubutı yig" tidi ben ança tir men; "ben Bilge Tunyukuk. Altun Y1şıg aşa keltimiz İrtiş Ögüzig keçe keltimiz kelmiş alp" tidi tuymad. Tengri, Umay, 1duk yirsub basa berti erinç "neke tezer biz öküş tiyin neke korkur biz az tiyin ne basınalım tegelim" tidim tegdimiz yuludımız ekinti kün kelti örtçe kızıp kelti süngüşdümiz bizinte eki uçı sıngarça artuk erti Tengri yarlıkaduk üçün öküş tiyin biz korkmadımız süngüşdümiz Tarduş şadra udı yayndımız kaganın tutdumız yabgusın şadın anta ölürti eligçe er tutdumız ol ok tün bodunın sayu ıtdımız ol sabıg işidip On Ok beyleri bodunı kop kelti yükünti.

${ }^{42}$ Gömeç, Kök Türk Tarihi, s.59-60.

${ }^{43}$ Bakınız, Şine Usu Yazıtı, Güney tarafı, 1. satır: Karluk tapa...Kem Kargu...İrtiş Ögüzig Arkar Baş1...anta er kamış...yanta sallap keçdim bir yegirminç ay sekiz yegirmike...yolukdım Bolçu Ögüzde Üç Karlukıg anta tokıdım anta yana tüşdim.
} 
Kanuy: Bu ırmağa Terhin Yazıtında rastlıyoruz ${ }^{44}$. Moyun Çor Kagan iktidarını sağlamlaştırıp, yabgu ve şadları atadıktan sonra ${ }^{45}$ Ötüken'in batı ucunda Tez Başı'nda bir yaylak meydana getirdi, otağı orada kurdurdu, sınırını orada yaptırdı ve 750-753 yıllarını burada geçirdi. Bu Tez Başı'nın doğusunda, Kanuy ve Künüy nehirleri bulunuyordu ${ }^{46}$. Burası bugünkü Tuva'nın güneyinde ve Hayargas Göl'e dökülen kollar olmalıdır.

Kara Bulak: 752 yılında Tokuz Oguzlar ile Kırgızların Uygurlara karşı bir ittifak meydana getirdiklerine yukarıda da değindik. Ürüng Beg ve Kara Bulak'da otururlarken Kırgızlara elçi göndermişlerdir ${ }^{47}$. Bu cümlede geçen Ürüng Beg ve Kara Bulak, kitabenin ilk değerlendirilmesi sırasında asil begleri ve avam bulukı (?) şeklinde manalandırılmıştı ${ }^{48}$. Fakat biz bu iki kelimenin de yer adı ve Abakan'ın kuzeyinde olduğunu tahmin ediyoruz ${ }^{49}$.

Kara Köl: Kök Türk çağında, Tannu-Ola'nın kuzeyinde bulunan ve Kırgızların komşuları olan Azların 714'te bir isyanları söz konusudur. Fakat Kök Türkler tarafından tekrar itaata alındılar. Kara Köl'de yapılan bu savaş sırasında Köl Tigin kırk yaşına gelmiştir. Onların bozguna uğratılmalarında Köl Tigin'in şahsi gayretleri çok fazladır. Köl Tigin, Az il-teberi’ni bizzat kendisi yakalamıştı ${ }^{50}$. Azlarla savaşın gerçekleştiği Kara Köl bugünkü Mogolistan'ın batı taraflarında, Tuva'nın güneyindedir. 715 yılı da Kök Türk ülkesinde isyanlar ve karışıklıkların fazlalaştığı bir zamana rastlar. Kapgan Kagan ihtiyarlamış yaşına rağmen tutarsız hareketlerde bulunuyordu. Hatta 714 yılında, imparator Hsüan-tsung'a bir elçi göndererek bir Çinli prensesle daha evlenmek istemişti ${ }^{51}$. Bu sırada kendine bağlı boylara karşı olan tutumu da değişti.

\footnotetext{
44 S.Gömeç, “Terhin Yazıtının Tarihi Açıdan Değerlendirilmesi”, DTCF. Tarih Araştırmaları Dergisi, 27/28, Ankara 1996, s.74.

${ }^{45}$ Gömeç, Uygur Türkleri..., s.28-29.

${ }^{46}$ Bakınız, Taryat-Terhin Yazıtı, Batı tarafı, 5. satır: yaylagım Ötüken kuzı kidin uçı Tez Başı öngdüni Kanuy Künüy...

Ayrıca bakınız, Tez II Yazıtı, Güney tarafı, 2. satır: Tezig Kasar kurıg kontı çıt tikdi örgin yaratdı yayladi.

${ }^{47}$ Bakınız, Şine Usu Yazıtı, Doğu tarafı, 10. satır: Yime yurtın yagıdıp gelmiş Ürüng Begig, Kara Bulakıg anı olurmış Kırkız tapa er ıdmış.

${ }^{48}$ G.J.Ramstedt, "Zwei Uigurische Runeninschriften in der Nord-Mongolei”, Journal de la Sociètè Finno-Ougrienne, 30, Helsinki 1913/18, s.23; H.N.Orkun, Eski Türk Yazıtları, C. I, İstanbul 1938, s.172;

${ }^{49}$ Gömeç, "Şine-Usu Yazıtında...”, s.431.

${ }^{50}$ Bakınız, Köl Tigin Yazıtı, Kuzey tarafı, 2-3. satırlar: Az bodun yagı boltı Kara Költe süngüşdümiz Köl Tigin bir kırk yaşayur erti Alp Salçı akın binip oplayu tegdi Az ilteberig tutd1 Az bodun anta yok bolt1.

${ }^{51}$ Gömeç, Kök Türk Tarihi, s.63.
} 
Kargu: Moyun Çor'un 752'de ülke dirliğini sağladıktan sonra konargöçer olarak yaşadığı su kıyalarından birisidir $\mathrm{ki}^{52}$ Burgu Nehrinden söz ederken, buraya da değinilmiştir. Dolayısıyla Selenge ve Orkun'un kollarından birisi olmalıdır.

Kazluk Köl: Şine Usu Yazıtının güney tarafı, 2. ve 3. satırlarında iki göl adına rastlıyoruz. Bunlar; Kazluk ve Taygun gölleridir. Buraların önemli tarihî olaylara sahne olduğu açıktır. Ancak yazıtın ilgili yerleri maalesef silindiğinden bu hadiseleri ortaya çıkarmak mümkün değildir. Burada adı geçen Kazluk Köl ve Taygun Köl, Altun Yış'ın batı taraflarında, yani Karluk, Basmıl sahasındaki göllerden birileri olmalıdır ${ }^{53}$. Bununla beraber biz Kazluk veya Kazılık adını Dede Korkut Hikayelerinde de görmekteyiz. Yer itibarıyla Kazılık Dağı bugünkü Güney Kazakistan'dadır. Ama Dede Korkut Hikayelerindeki konumuna baktığımızda, burası herhalde Doğu Anadolu veya Kafkasya sahasındadır. Buna bağlı olarak Kafkasya sıradağlarının Dede Korkut'ta Kazılık biçiminde kaydedildiğine dair iddialar vardır $^{54}$. Bu da demektir ki atalarımız yine ta Orta Asya'daki bir coğrafi adı, batıya göçerlerken beraberlerinde getirmişler ve vatan yaptıkları o topraklarda da kullanmışlardır.

Kem: Türk tarihinde ve kültüründe önemli bir yere sahip olan Kem'i yani Yenisey Nehrini birkaç kitabede görüyoruz. Öncelikli olarak Bilge Kagan Yazıtında; Bilge 26 yaşındayken, yani 709 yılında Kırgızlarla işbirliği yapan Çiklerin $^{55}$ üzerine Kem Irmağ 1 geçilerek yürünmüş ve Ürpen'de ${ }^{56}$ yapılan savaşta Çik ordusu mağlup edilerek dağıtılmıştı ${ }^{57}$. Aynı sefer sonunda Azlar ${ }^{58}$ da itaata alındılar.

Kem'in adına bir kez de Uygur döneminde yine Çiklerin ayaklanması vesilesiyle tesadüf olunur. 750 yılında Çiklere karşı bir sefer düzenleyen Uygur kaganı Kem'de onları mağlûp ettikten sonra, 751 senesinde Kasar'ın batısında, ki muhtemelen Tez Nehrinin batısı, otağ kurdurmuştur. Doğu tarafı dokuzuncu satırda anlatılan bu hadiselere göre; yazı burada geçirerek,

\footnotetext{
${ }^{52}$ Bakınız, Taryat-Terhin Yazıtı, Batı tarafı, 4. satır: Sekiz Selenge Orkun Togla Sebintürdü Kargu Burgu ol yirimin subımın konar köçer ben.

${ }^{53}$ Gömeç, a.g.m., s.432.

${ }^{54}$ O.Ş.Gökyay, Dedem Korkudun Kitabı, İstanbul 1973, s.336.

${ }^{55}$ Çikler hakkında daha geniş bilgi için bakınız, S.Gömeç, "Kök Türkçe Kaynaklarda Geçen Boy ve Kavimler Üzerine: Çikler”, Türk Kültürü, 32/370, Ankara 1994.

${ }^{56}$ Ürpen, Kögmen Dağlarının güneyi ile Yenisey'in Kemçik ve Elegeş kollarının birleşme noktalarının üzerinde olsa gerek!

${ }^{57}$ Bakınız, Bilge Kagan Yazıtı, Doğu tarafı, 26. satır: Altı otuz yaşıma Çik bodun Kırkız birle yagı bolt. Kem keçe Çik tapa süledim Ürpente süngüşdim süsin sançdım.

58 Azlar konusunda bakını, S.Gömeç, "Kök Türkçe Kaynaklarda geçen Boy ve Kavim Adları: Azlar", Belleten, 58/221, Ankara 1994.
} 
kitabesini yazdırmış ve herhalde bu sırada Tatarlarla küçük bir mücadele yapmıştır ${ }^{59}$.

Yenisey Nehri'nin toplam uzunluğu 3800 km'dir. Kaynakları Mogolistan'ın kuzeyinden itibaren başlamaktadır. Özellikle Hakas, Tuva, Altay gibi Türk topluluklarının etrafını yurt tuttuğu bereketli bir sudur.

Kergü: Bilindiği üzere babaları Kutlug Bilge öldükten sonra Uygur tigini Moyun Çor ile ağabeyi Tay Bilge Tutuk arasında kıyasıya bir mücadele başladı. Çin kaynaklarında fazla bir malûmata rastlanmamasına rağmen Kök Türkçe belgelerde bu kavga teferruatıyla anlatılmıştır. Moyun Çor birçok çağnılar yapmış olmasına rağmen kardeşi ve yandaşlarını ikna edememişti ${ }^{60}$. Bunun üzerine $\mathrm{O}$, Selenge yakınlarında Yılan Kol'dan Şıp Başı'na kadar asker gönderdi, onlar da Kergü ve Sakış'dan ${ }^{61}$ yürüyerek geldiler. Beşinci ayın 29'unda tekrar kardeşiyle savaşa tutuştu. Onu Selenge Nehri'nin kıyısına sıkıştırarak, büyük bir bozguna uğrattı. Bu yüzden Moyun Çor kitabesinde, halkın kötü kişilerin peşine takılmasından dolayı, ölüpmahvolduğunu da dile getirmiștir ${ }^{62}$. Biz iște burada söz konusu olan Kergü'nün, Selenge'nin kuzeyinde olduğunu tahmin ediyoruz ${ }^{63}$.

Keyre Başı: Şine Usu Yazıtının kuzey tarafı 6. satırında geçen Keyre ile 7. satırda bir Keyre Başı ve Üçbirkü (veya Üç-bir-ekü) adını görüyoruz. Keyre Başı ve Üçbürkü hususunda bugüne kadar birşey söylenmemiştir. Ancak daha sonraki satırlarda karşılaştığımız yer adlarına bakacak olursak, buraları Ongin Irmağının güney-doğu taraflarında olmalıdır ${ }^{64}$. 739-40 yıllarında On Uygur ittifakı meydana gelmiş, Moyun Çor'da babası Köl Bilge'ye bağlı olarak Kök Türk Kaganlığına tabi olan topraklar üzerinde faaliyetlere girişerek Keyre, Keyre Başı ve Üçbirkü’ de babasının askerleriyle

\footnotetext{
${ }^{59}$ Bakınız, Şine Usu Yazıtı, Doğu tarafı, 7-10. satırlar: Bars yılka Çik tapa yorıdım ekinti ay tört yegirmike Kemde tokıdım ol yıl ol bodun içikdi anta Kasar kurdan örgin ititdim çıt anta tokıtdım yay anta yayladım yaka anta yakaladım belgümin bitigimin anta yaratıtdım ançıp ol yıl küzün ilgerü yorıdım Tatarıg ayıtdım tabışkan yıl bişinç ayka tegdim ulu yılka Ötüken Yış başınta Süngüz Başınta ıduk baş kidinte Yabaş Tokuş beltirinte anta yayladım örgin anta yaratıtdım çıt anta tokıtdım bing yıllık tümen künlik bitigimin belgümin yassı taşka yaratıtdım.

${ }^{60}$ Gömeç, Uygur Türkleri..., s.26-27.

${ }^{61}$ Kergü ile aynı bölgede olmalıdır.

${ }^{62}$ Bakınız, Şine Usu Yazıtı, Doğu tarafı, 2-5. satırlar:... ebin barkın yılkısın yulımadın kıyın aydım turguru kotım kentü bodunım tidim udı kelin tidim kodıp bardım kelmedi...Selenge kidin Yılan Kol birdin sıngar Şıp Başınga tegi çerig itdim Kergün Sakışın Şıp başıng yüre kelti...Selenge tegi çerig itdi bişinç ay tokuz otuzka süngüşdim anta sançdım Selengeke sıka sançdım yazı kıltım öküşi Selenge kodı bardı ben Selenge keçe udı yorıdım süngüşde tutıp on er ıtdım Tay Bilge Tutuk yablakın üçün bir eki atlıg yablakın üçün kara bodunım öltin yetdin yana içik ölmeçi yelmeçi sen tidim yiçe işig küçig ebirgil tidim.

${ }^{63}$ Gömeç, "Şine-Usu Yazıtında...", s.430.

${ }^{64}$ Gömeç, a.g.m., s.428.
} 
birleşmiş, Yılan yılında (741) Türk topraklarında bir karışıklığa sebep olmuştur ${ }^{65}$.

Kök Öng: 687 senesinde İl-teriş komutasındaki Kök Türk orduları, Oguzların hakimiyeti altında bulunan Ötüken'in merkezi Ordu Balık'a doğru harekete geçtiler. Bu sırada Çinliler ve Kıtanlar da Oguzlarla müttefiktiler. Çinliler ve Kıtanlar sürekli yaptıkları gibi müttefiklerini yalnız bıraktılar ${ }^{66}$. Kök-Öng geçilerek ordu Ötüken Yış’a doğru sevkedilmiş, inek ve yük hayvanlarıyla yürüyen Oguzların üç bin askeri, iki bin kişilik Kök Türk ordusuyla karşılaşmış ve Kök Türk inancına göre Tanrı izin verdiği için yenilmişlerdir ${ }^{67}$. Togla kenarında yapılan bu savaşta Oguz beyi Baz Kagan öldürüldü (687). Oguzların bu gözü pek başbuglarının Tengri adında bir oğlunun olduğunu da bilmekteyiz ${ }^{68}$. Ancak onun Kök Türk savaşlarına katılıp-katılmadığı hakkında bir malumata sahip değiliz. Adına taş yazılan bu çocuğun belki de Kök Türklerle son vuruşmadan biraz önce öldüğünü söyleyebiliriz. Eğer Kök Türk savaşlarına katılmış olsaydı, Orkun Yazıtlarında onun da adının geçmesi gerekirdi. Halbuki bu belgelerde böyle bir șeye rastlamıyoruz.

Netice itibarıyla Kök Öng, umumiyetle araştırmacılar tarafından bugünkü Ongin Nehri'yle birleştirilmektedir ${ }^{69}$.

Künüy: Bu ırmağın adıyla, biz Terhin Yazıtının batı tarafı, 5. satırında karşılaşıyoruz. Moyun Çor Kagan sahip olduğu coğrafya hakkında bilgi verirken Kanuy ve Künüy'ü de anmaktadır ${ }^{70}$. Bu nehirlerin yerini daha önce Kanuy bahsinde anlatmaya çalıştık.

Orkun: Türk tarihinin ve kültürünün en önemli nehridir. Kelime "or" ve "kun/kün" isimlerinin birleşmesinden teşekkül etmiş ve toplumun, milletin merkezi, karargâhı manasına geliyor, olmalıdır. Neredeyse bir baştan, bir başa Kutlu Ötüken'i dolaşır. Suyunun bir damlası için yüzyıllar boyunca Türkler can verip, kan dökmüşlerdir. Selenge Irmağı'nın ana kolu durumundaki bu su $1130 \mathrm{~km}$ uzunluğunda olup, şuanki Mogolistan'ın verimli ve hayvancılığa en müsait topraklarını meydana getirir. Kök Türk

\footnotetext{
${ }^{65}$ Bakınız, Şine Usu Yazıtı, Kuzey tarafı, 6-7. satırlar: Sü yorıtdı özimin öngre bınga başı ıdtı Keyrede öngdin yantaç...içgerip yana yorıdım Keyre Başınta Üçbirküde kan süsi birle katıldım.

${ }^{66}$ Gömeç, Kök Türk Tarihi, s.46.

${ }^{67}$ Bakınız, Tunyukuk Yazıtı, I. Taş, Güney tarafı, 8-9. satırlar: Kök Öngüg yoguru Ötüken Yışgaru udıztım ingek kölükin Toglada Oguz kelti süsi üç bing ermiş biz eki bing ertimiz süngüşdümiz Tengri yarlıkadı yayndımız ögüzke tüşti yaynduk yolta yime ölti.

${ }^{68}$ Baz Kagan'ın oğlunun adını biz Hangita-Hat Yazıtında görüyoruz. Bakınız, S.Gömeç, "Türk Tarihinin Kahramanları: 13- Baz Kagan”, Orkun, Sayı 64, İstanbul 2003.

${ }^{69}$ Gömeç, “Kök Türkçe Yazıtlarda Geçen...”, s.33.

${ }^{70}$ Bakınız, Taryat-Terhin Yazıtı, Batı tarafı, 5. satır: yaylagım Ötüken kuzı kidin uçı Tez Başı öngdüni Kanuy Künüy...
} 
Kitabeleri olarak bilinen, Türk tarihinin kıymeti hiçbir şey ile ölçülemeyecek eserleri de bu Orkun Havzası'ndadır. Abidelerin bulunduğu yer, geçmişte olduğu gibi bu gün de stratejik bir öneme sahiptir. Burası Orkun Vadisi'nin doğudan giriş kapısıdır ve en büyük düşman, yani Çin'den gelecek tehlikelere karşı da ilk engelin oluştuğu mevkidir ${ }^{71}$.

Orkun'un adını biz Şine Usu ve Terhin Yazıtlarında görmekteyiz. Uygur kuvvetleri 752 senesinde Basmıl ve Karluklarla bir savaş yapmıştır. Bu mücadelede, Moyun Çor Kagan'ın iki rakip Türk kabilesini yendikten sonra Orkun ve Balıklı nehirlerinin kavşağında otağını kurdurması ${ }^{72}$ vesilesiyle karşımıza çıkar. Ülke içindeki huzur sağlandıktan sonra kagan, Sekiz-Selenge, Orkun, Togla, Sebintürdü, Kargu ve Burgu'nun kıyılarında konar-göçer olarak hayatını sürdürdüğünü ${ }^{73}$ bildirmektedir.

Sebintürdü: Adına Terhin Yazıtında rastlıyoruz ${ }^{74}$. Burası Selenge'nin kollarından biri olmalıdır. İsmi geçen yerlere dikkat edilirse, hepsi Baykal'ın güneyinde ve Selenge Nehri etrafındadır ${ }^{75}$.

Sekiz Selenge: Burası da yine Moyun Çor'un vaktiğini geçirdiği ve ziraata müsait mekanlar vasitasıyla Orkun, Togla, Sebintürdü, Kargu ve Burgu'nun adıyla birlikte anılmaktadır ${ }^{76}$.

Selenge: Yenisey'in hemen güney-doğusunda kutlu Ötüken topraklarında, Selenge ve onun en büyük kolu olan Orkun'a vardır. Orkun ve Selenge; biri ana, diğeri oğul gibidir ve Baykal Gölüne dökülür ${ }^{77}$. Selenge adı, Terhin Yazıtı, batı tarafı 4. satırda, yukarıda izah ettiğimiz üzere Sekiz Selenge vesilesiyle geçmekle beraber yine Şine Usu Kitabesinde; Moyun Çor Kagan'ın yaylak ve kışlak mıntıkalarından biri olarak anılmaktadır ${ }^{78}$. Ayrıca bu yazıtta, kardeşi Tay Bilge Tutuk'la 748-749'larda yaptığı mücadeleleri hatırlatırken Selenge adıyla karşılaşmaktayız. O kardeşi ve

\footnotetext{
${ }^{71}$ S.Gömeç, “Orkun”, Orkun, Say1 46, İstanbul 2001.

${ }^{72}$ Bakınız, Şine Usu Yazıtı, Güney tarafı, 8-10. satırlar:...Tabgaçdakı Oguz Türk taşıkmış anta katılmış anta beyler...biş yüz kedimlig yadag bir eki şaşıp kelti küngim kulım bodunı tengri yer anta ayu birti anta sançdım...Karluk tapa tezip kirti anta yana tüşip Orkun Balıklıg beltirinte el örginin anta örgipen ititdim...

${ }^{73}$ Bakınız, Taryat-Terhin Yazıtı, Batı tarafı, 4. satır: Sekiz Selenge Orkun Togla Sebintürdü Kargu Burgu ol yirimin subımın konar köçer ben.

${ }^{74}$ Bakınız, Taryat-Terhin Yazıtı, Batı tarafı, 4. satır:..Ötüken eli tegiresi ikin ara 1lgam tarıglagım Sekiz Selenge Orkun Togla Sebintürdü Kargu Burgu ol yirimin subımın konarköçer ben.

${ }^{75}$ Gömeç, "Kök Türkçe Yazıtlarda Geçen...”, s.34.

${ }^{76}$ Bakınız, Taryat-Terhin Yazıtı, Batı tarafı, 4. satır.

${ }^{77}$ Gömeç, "Orkun”, s.32; Gömeç, "Şine-Usu Yazıtında...,", s.428.

${ }^{78}$ Bakınız, Şine Usu Yazıtı, Kuzey tarafı, 2. satır: Ötüken tegresi eli ikin ara olurmış subı Selenge ermiş.
} 
taraftarlarını muhtemelen Selenge Nehri'nin kıyısına sıkıştırarak yendi ${ }^{79} . \mathrm{Bu}$ sırada kardeşi Tay Bilge Tutuk'un da öldürülmüş olduğunu sanıyoruz ${ }^{80}$.

Bunun dışında Moyun Çor döneminin sonuna doğru Selenge kıyısında Bay Balık adında bir şehir yaptırılmıştır ki ${ }^{81}$ bu yüzden de Selenge Irmağının adını görüyoruz. Sogdlu ve Çinli ustalara kurdurulan bu şehrin kalıntıları halâ durmaktadır ${ }^{82}$.

Bilge Kagan Yazıtında ise Selenge ismi Uygur olayları sebebiyle karşımıza çıkar. Köl Tigin ve Bilge tahtı ele geçirdikleri sırada Kök Türk ülkesindeki karışıklık henüz sona ermemişti. Bilge Kagan'ın ilk savaşı, Uygur il-teberine karşı 716 yılının sonlarına doğru, Selenge Nehri boyunda, Kargan Kısıl'da meydana geldi. Uygurların yurtları dağıtıldı, Uygur il-teberi yüz kadar adamıyla doğuya doğru kaçt ${ }^{83}$. Uygurlar burada büyük bir zaiyat verdiler ve bundan epey bir süre etkilenerek Kök Türk Börülü (Aşina) ailesine karşı ters bir harekette bulunamadılar ${ }^{84}$.

Şıp Baş1: Burası da Moyun Çor'un, kardeşi Tay Bilge Tutuk'la olan savaşlarından dolayı, Şine Usu Yazıtında geçer ${ }^{85}$. Şıp Başı da herhalde Selenge'nin doğu taraflarında olmalıdır ${ }^{86}$.

Taygun Köl: Daha önce 752 yılında, Uygurlara karşı Tokuz Oguz, Kırgız, Karluk ve Çiklerin bir ittifak meydana getirdiklerini bildirmiştik. İşte Moyun Çor, Şine Usu Yazıtında Çikleri yola getirdikten sonra onlara 1şbara, tarkan ve tutuklar atadığını söyledikten sonra Taygun Kölde ordusunu toparlayıp, Karluk ve Basmılların niyetini öğrenmiş, onlarla da savaşmıştır ${ }^{87}$.

\footnotetext{
${ }^{79}$ Gömeç, Uygur Türkleri..., s.26-27.

${ }^{80}$ Bakınız, Şine Usu Yazıtı, Doğu tarafı, 2-4. satırlar: Kentü bodunım” tidim "udu keling” tidim kodup bardım kelmedi yiçe ertim Burguda yetdim törtünç ay tokuz yangıka süngüşdim sançdım anta yılkısın barımın kızın koduzın kelürtim bişinç ay udu kelti Sekiz Oguz Tokuz Tatar kalmatı kelti Selenge kidin Yılan Kol birdin sıngar Şıp Başınga tegi çerig itdim Kergün Sakışın Şıp başıng yüre kelti...Selenge tegi çerig itdi bişinç ay tokuz otuzka süngüşdim anta sançdım Selengeke sıka sançdım yazı kıltım öküşi Selenge kodı bardı ben Selenge keçe udı yorıdım.

${ }^{81}$ Gömeç, a.g.e., s.37-38.

${ }^{82}$ Bakınız, Şine Usu Yazıtı, Batı tarafı, 5. satır: Sugdak Tabgaçka Selengede Bay Balık yapıtı birtim.

${ }^{83}$ Bakınız, Bilge Kagan Yazıtı, Doğu tarafı, 37. satır: Selenge kodı yorıpan Kargan Kısılta ebin barkın anta bozdım...Uygur il-teber yüzçe erin ilgeri tezip bardı.

${ }^{84}$ Gömeç, Kök Türk Tarihi, s.68.

${ }^{85}$ Bakınız, Şine Usu Yazıtı, Doğu tarafı, 3-4. satırlar: Sekiz Oguz Tokuz Tatar kalmatı kelti Selenge kidin Yılan Kol birdin sıngar Şıp Başınga tegi çerig itdim.

${ }^{86}$ Gömeç, "Şine-Usu Yazıtında...", s.430.

87 Bakınız, Şine Usu Yazıtı, Güney tarafı, 2-5. satırlar: Çik bodunıg bıngam süre kelti...çıtımın yayladım yaka anta yaladım Çik bodunka tutuk birtim ışbaras tarkat anta ançuladım...Kazluk Költe...Taygun Költe tiriltim bidgüçi er anta ıtdım er kelti Kara Yotulkan keçip kelirti ben utru yorıdım...Karluk tapa er 1 dmış...içre ben bulgayın timiş taşdından...Basmıl yagıdıp ebimrü bardı anı içgermedim taşdından Üç Karluk üç ıduk...bişinç
} 
Burada anılan Taygun Köl'ün biz, Altun Yış'ın batı taraflarında, yani Karluk, Basmıl sahasındaki göllerden biri olduğunu sanıyoruz ${ }^{88}$.

Tez Başı: Moyun Çor Kagan hakimiyetini sağlamlaştırdıktan sonra adına dikilen kitabelerinde Tez Nehri'nin batısında bir hükümdar otağı kurdurduğunu, 750-753 yıllarını burada geçirdiğini haber veriyor ${ }^{89}$. Terhin Kitabesinde ayrıntılı olarak anlatılan bu hadiseye Tez II Yazıtında da değinilmektedir ${ }^{90}$. Adı geçen vesikalardan yola çıkacak olursak, Tez Nehri civarları kaganın yazlık merkezi durumundaydı. Devletin esas başkenti Orkun Irmağı kıyısındaki Ordu Balık (Karabalgasun) şehriydi.

Tez Nehri günümüz itibarıyla Mogolistan sınırları içerisinde bulunan ve Ubsu Köl'e dökülen bir ırmaktır. Belgelerden de anlaşılacağı üzere Tez Nehri boyları geçmişte ve günümüzde Türklerin hayatlarını sürdürdüğü önemli akarsulardan birisidir. Burası ayrıca Uygur halkı için de önem arzediyordu ki, kaganlığın temellerinin atıldığı yıllarda ilk Uygur hükümdarları bu suyun etrafında yaşadılar. Ayrıca orada Türk tarihinin ve kültürünün en mühim kaynaklarından olan kitabelerini de yazdırdılar.

Togla: Mogolların Tuul, bizim Togla dediğimiz bu akarsu Orkun'un doğu kollarından birisidir. Bilge Kagan, Tunyukuk ve Terhin yazıtlarında kayıtlıdır. İlk önce İl-teriş, Tunyukuk ve Kapgan'ın Kök Türkleri yeniden derleyip-toparlamaları sırasındaki olaylar anlatılırken Togla kıyısındaki savaştan söz edildiğini görmekteyiz. 687' de Togla Nehri kıyısında meydana gelen harpte Oguzların mağlubiyeti hususunda; "Kök Öng geçilerek ordu Ötüken Yış'a doğru gönderildi, inek ve yük hayvanlarıyla yürüyen Oguzların üç bin askeri, iki bin kişilik Kök Türk ordusuyla karşılaştı ve Kök Türk inancına göre Tanrı izin verdiği için mahvoldular"91 deniyor.

$\mathrm{Bu}$ ırmak, 715 senesindeki Oguz savaşları vesilesiyle de karşımıza çıkmaktadır ${ }^{92} .716$ yılına kadar süren bu savaşların sonunda Oguzların büyük bir bozguna uğrayarak bir kısmının Çin'e gittikleri anlaşılmaktadır. Herhalde bu yenilgi onlara çok ağır gelmiştir. Bu sırada Çin imparatorluğunun sürekli

ay altı otuzka süngüşdim anta sançdım..."

${ }^{88}$ Gömeç, a.g.m., s.432.

${ }^{89}$ Bakınız, Taryat Terhin Yazıtı, Batı tarafı, 1-2. satırlar: Tengride Bolmış İl Etmiş Bilge Kagan İl Bilge Katun atıg atanıp Ötüken kidin uçınta Tez Başınta örgin anta etitdim çit anta yaratıtdım bars yılka yılan yılka eki yıl yayladım ulu yılka Ötüken ortusınta Süngüz Başkan 1duk baş kidininte yayladım örgin bunta yaratıtdım çit bunta tokıtdım.

90 Bakınız, Tez II Yazıtı, Güney tarafı, 2. satır: Tezig Kasar kurıg kontı çıt tikdi örgin yaratdı yayladi.

${ }^{91}$ Bakınız, Tunyukuk Yazıtı, I. Taş, Güney tarafı, 8-9. satırlar: Kök Öngüg yoguru Ötüken Yışgaru udıztım ingek kölükin Toglada Oguz kelti süsi üç bing ermiş biz eki bing ertimiz süngüşdümiz Tengri yarlıkadı yayndımız ögüzke tüşti yaynduk yolta yime ölti.

${ }^{92}$ Bakınız, Bilge Kagan Yazıtı, Doğu tarafı, 29-30. satırlar: Tokuz Oguz mening bodunım erti tengri yir bulgakın üçün yagı boltı bir yılka tört yolı süngüşdümiz ang ilki Togu Balıkda süngüşdümiz Togla Ögüzig yüzeti keçip süs..." 
Türk topluluklarına kucak açmasının elbette çeşitli sebepleri vardı. Herşeyden önce birbirleriyle kavga eden, birlik ve beraberlikten yoksun Türklerin kullanılması çok kolayd ${ }^{93}$.

Terhin Kitabesinde ise yukarıda birkaç defa değindiğimiz gibi, Moyun Çor' un ekip-biçtiği mahaller arasında Togla boyları da gösterilmektedir ${ }^{94}$.

Tokuş: 751 yilında Moyun Çor Kagan'ın muhtemelen Ubsu Köl civarlarında $^{95}$, Yabaş ve Tokuş adlı suların kavşağında yazı geçirdiğini Şine Usu Yazıtından öğrenmekteyiz ${ }^{96}$.

Türgi-Yargun Köl: Herhalde, 705 veya 706 yılında Kök Türk ordularının bir Bayırku seferi vardır. Bu sıralarda Bayırkuların ${ }^{97}$ Ulug İrkinleri düşman olmuş, Türgi-Yargun Kölde yapılan savaşta Bayırku kuvvetleri bozguna uğratılmıştı ${ }^{98}$. Bilge Kagan Yazıtında ve Çin kaynaklarında anlatılmayan bu savaş sonunda Ulug İrkin kendi canını zor kurtarabilmişti ${ }^{99}$. Söz konusu gölün biz, Togla yakınlarında olduğunu sanmaktayız.

Uçuz Köl: Bu gölün adını biz ilk defa Tez II Yazıtında görmekteyiz ki, bu anıt Moyun Çor'un oğlu Bögü Kagan adına dikilmiştir ${ }^{100}$. Bu kitabede anlatılanlardan yola çıkarak, 687 tarihindeki Kök Türk-Tokuz Oguz mücadelelerine atıf yapıldığı anlaşılmaktadır. 687'de Baz Kagan'ın öldürülmesi sırasında meydana gelen bu olaylar hakkında Tez II ve Terhin kitabelerinde şöyle yazılmaktadır: "Bozguncuların başı tarafından baskın yapılıp Uçuz Köle ileri gelenleri dökülmüştür...Bedi Bersil ve Kadır Kasar oraya varmıştır. O halkım orada büyük kavga yaptı”"101; “...Uçuz Köl'e ileri

\footnotetext{
${ }^{93}$ Gömeç, Kök Türk Tarihi, s.63-65.

${ }^{94}$ Bakınız, Taryat-Terhin Yazıtı, Batı tarafı, 4. satır: Sekiz Selenge Orkun Togla Sebintürdü Kargu Burgu ol yirimin subımın konar köçer ben.

${ }^{95}$ Gömeç, "Kök Türkçe Yazıtlarda Geçen...", s.35.

${ }^{96}$ Bakınız, Şine Usu Yazıtı, Doğu tarafı, 9-10. satırlar: Ulu yılka Ötüken Yış başınta Süngüz Başkan ıduk baş kidinte Yabaş Tokuş beltirinte anta yayladım örgin anta yaratıtdım çıt anta tokıtdım bing yıllık tümen künlik bitigimin belgümin yassı taşka yaratıtdım.

${ }^{97}$ Çin kaynaklarında Tölöslerin bir boyu olarak geçen Bayırkuları, ayrıca Tokuz Oguz federasyonu içerisinde de görmek mümkün olup; Kök Türklerin doğusunda, Oguzların ve Togla Nehrinin kuzeyinde yaşıyorlardı. Çince Pa-ye-ku şeklinde transkripsiyon edilen Bayırku adı, tibetçe metinlerde Bayarbgo ve Bayarkata biçiminde yazılıdır. Geniş bilgi için bakınız, S.Gömeç, "Kök Türkçe Kaynaklarda Geçen Bayırkular", DTCF. Tarih Araştırmaları Dergisi, 16/26, Ankara 1994.

${ }^{98}$ Bakınız, Köl Tigin Yazıtı, Doğu tarafı, 34. satır: Anta kisre Yir Bayırku Ulug İrkin yagı boltı anı yanyıp Türgi Yargun Költe bozdımızUlug İrkin azkınya erin tezip bardı.

${ }^{99}$ Gömeç, Kök Türk Tarihi, s.55.

100 Tez II Yazıtı için bakınız, S.Gömeç, “Bögü Kagan'ın Yazıtı: Tez II”, Türk Dünyası Tarih Dergisi, Say1 124, İstanbul 1997.

${ }^{101}$ Bakınız, Tez II Yazıtı, Kuzey tarafi, 3-4. satırlar:...buzuk başın akıza Uçuz Kölke atlıgın töke barmış...Bedi Bersil Kadır Kasar anta barmış ol bodunım keng kerişdi...
} 
gelenleri dökülmüş. Kadır Kasar, Bedi Bersil, Yatız Oguz...”"102 . Biz burada adı geçen şahıslar hakkında Uygur Tarihi ve Kültürü adlı kitabımızda gerekli izahlarda bulunduk ${ }^{103}$. Dolayısıyla Uçuz Köl'ün de Togla Nehri civarlarında olmasi lazımdır.

Yabaș: Söz konusu nehri Kem ve Tokuş hakkında açıklamalarda bulunurken zikretmiştik. 750-751 yılı olayları vesilesiyle anılan ${ }^{104}$ bu akarsu da Tokuş ile aynı yere dökülüyor olmalıdır.

Yar Ögüz: Şine Usu ve Terhin yazıtlarının, kuzey tarafı ile doğu yüzünün 8. satırlarında geçen ırmaklardan birisi de budur. Moyun Çor, son Kök Türk kaganlarından Ozmış’ın hareketine engel olmadan önce Üç Tuglıg Türk Bodunın ${ }^{105}$ başında Kara Kum'u aşıp gelen Kutlug Yabgu ile karşılaşmış ve yapılan savaşlar sonunda onu ortadan kaldırmıştı1 ${ }^{106} .742$ 'deki Karluk, Uygur ve Basmılların Kök Türklere karşı bu galibiyetlerinden sonra onlar, Basmılların liderini kagan seçip aralarında bir idarî taksimata gittiler. Uygurların önderi doğu bölgesine, Karluk il-teberi de On Ok yurdunu yönetmeye başladı. Bu sırada, "Kök Türk Kaganlığında Ozmış Tigin han olmuştu. Moyun Çor, Koyun yılında (743) onun da üzerine yürüdü. Talihsiz Ozmış Tigin ele geçirildi, Kök Türk halkına büyük bir darbe indirildi. 743 yılında Kök Türk kaganı Ozmış öldürüldü ve kellesi Çin başkentine gönderildi ${ }^{107}$.

İki kitabede, aynı olayların anlatılması sırasında rastladığımız bu Yar Ögüz'ün, Huang-ho'nun kuzeyinde olduğu söylenmektedir ${ }^{108}$.

Yaşıl Ögüz: Çin'in kuzeyindeki Sarı Su olarak da anılan ırmaktır. Esasında ta Hunlar çağından beridir, Türklerle Çinliler arasındaki tabî̂ sınırlardan birisidir. Kök Türk Yazıtlarından olan Tunyukuk Kitabesinde rastladığımız, Taluy Ögüz'den de bu nehrin kastedildiği anlaşılıyor ${ }^{109}$. Köl Tigin ve Bilge Kagan Yazıtlarında Çin'e yapılan seferler vesilesiyle

\footnotetext{
102 Bakınız, Taryat Terhin Yazıtı, Doğu tarafı, 2. satır:...bodunı akıza barmış Uçuz Kölke atlıgın töke barmış Kadır Kasar Bedi Bersil Yatız Oguz...

${ }^{103}$ Gömeç, Uygur Türkleri..., s.19-20.

${ }^{104}$ Bakınız, Şine Usu Yazıtı, Doğu tarafı, 9-10. satırlar: Ulu yılka Ötüken Yış başınta Süngüz Başınta 1duk baş kidinte Yabaş Tokuş beltirinte anta yayladım örgin anta yaratıtdım çıt anta tokıtdım bing yıllık tümen künlik bitigimin belgümin yassı taşka yaratıtdım.

${ }^{105}$ Üç Tuglıg Türk Bodun için bakınız, Gömeç, Uygur Türkleri..., s.22-23.

${ }^{106}$ Bakınız, Şine Usu Yazıtı, Kuzey tarafı, 8. satır; Terhin Yazıtı, Doğu tarafı, 8. satır; Kara Kum aşmış Kögürde Kömür Tagda Yar Ögüzde Üç Tuglıg Türk Bodunka yitinç ay tört yigirmike....anta tokıttırdım.

${ }^{107}$ Gömeç, Uygur Türkleri..., s.23.

108 L.Bazin, "Notes de Toponymie Turque Ancienne", Acta Orientalia, 36/1-3, Budapest 1982, s. 60.

${ }^{109}$ Bakınız, Tunyukuk Yazıtı, I. Taş, Doğu tarafı, 1-2. satırlar: Türk bodun kılıngalı Türk Kagan olurgalı Şantung Balıkka Taluy Ögüzke tegmiş yok ermiş kaganıma ötünip sü ilttim Şantung Balıkka Taluy Ögüzke tegürtdim üç otuz balık sıdı.
} 
anılmaktadır $\mathrm{ki}^{110}$ bu hususta şunlar kayıtlıdır: Amcam kagan ile doğuda Yaşıl Ögüz'e, Şantung Yazı'sına (ovasına), batıda Temir Kapı'ya, Kögmen'i aşarak Kırgız ülkesine kadar ordu sevkettik. Toplam 25 defa akın yaptık. Onüç kere savaştık ${ }^{111}$.

Yılan Kol: Selenge'nin batısındaki parçalarından birisi olduğunu düşünmekteyiz. Çünkü Şine Usu Yazıtından böyle bir anlam çıkmaktadır ${ }^{112}$. $\mathrm{Bu}$ nehirin yazıtta ne sebeple geçtiğini yukarıda, ilgili yerlerde açıkladık.

Yinçü Ögüz: Türk coğrafyasının en önemli ırmaklarından birisi de budur. Günümüzde Sir Derya olarak bilinen bu akarsuya atalarımız Yinçü Ögüz demişlerdir ki "İnci Nehri” anlamına geliyor. Amu Derya ve Sir Derya ırmakları çevresi ile ikisinin arası bilindiği üzere tarihte Maveraünnehir olarak anılır. Ayrıca Türklerin yerleştiği en eski toprak parçalarından bir bölümünü teşkil eder. Hem geçmişte hem günümüzde bu topraklar Oguz yurdu olarak da tanınır. Bu iki su da Aral Gölüne dökülmektedir. Özellikle Sovyet döneminde uygulanan tarım politikaları yüzünden Amu Derya ve Sir Derya'nın Aral'a giden havzası üzerinde oynamalar yapıldığından, her iki nehrin suyunda da azalmalar görülmüşsür ${ }^{113}$.

Orkun Yazıtlarından öğrendiğimize göre; 710 yılının sonlarına doğru Sogdları düzene sokmak için yapılan bir Temir Kapı seferi vardır. Köl Tigin Yazıtında bölgeye asker sevki hususunda; Sogd halkını yeniden düzenlemek için Yinçü Ögüz geçilerek, Temir Kapı'ya kadar bir ordu yollandı ${ }^{114}$ denmektedir. Tunyukuk Yazıtında ise bu olay şöyle anlatılıyor: Yinçü Ögüz geçilip, Tinsi oglunun yattığı kutlu Ek Tag'a ve oradan Temir Kapı'ya ulaşıld $1{ }^{115}$. Yine Bilge Kagan yaptığı seferlerden bahsederken; "batıda Yinçü Ögüz üzerinden Temir Kapı'ya kadar ordu çıkardığını"116 söylüyor. Biz meşhur Köl İç Çor'un yazıtında da benzer ifadeleri görmekteyiz ${ }^{117}$.

\footnotetext{
${ }^{110}$ Gömeç, Kök Türk Tarihi, s.50-52.

${ }^{111}$ Bakınız, Köl Tigin Yazıtı, Doğu tarafı, 17-18. satırlar; Bilge Kagan Yazıtı, Doğu tarafı, 15. satır: Eçim kagan birle ilgerü Yaşıl Ögüz, Şantung Yazıka tegi süledimiz kurıgaru Temir Kapıgka tegi süledimiz Kögmen aşa Kırkız yiringe tegi süledimiz kamagı biş otuz süledimiz üç yigirmi süngüşdümiz.

${ }_{112}$ Bakınız, Şine Usu Yazıtı, Doğu tarafı, 3. satır: Selenge kidin Yılan Kol birdin sıngar Şıp Başınga tegi çerig itdim.

${ }^{113}$ Gömeç, Türk Kültürünün..., s.15

${ }^{114}$ Bakınız, Köl Tigin Yazıtı, Doğu tarafı, 39. satır: Sogdak bodun iteyin tiyin Yinçü Ögüzig keçe Temir Kapıgka tegi süledimiz.

${ }^{115}$ Bakınız, Tunyukuk Yazıtı, II. Taş, Batı tarafı, 9. satır: Yinçü Ögüzig keçe Tinsi oglı yatıgma bengülig Ek Tagıg ertürtim.

${ }_{116}$ Bakınız, Köl Tigin Yazıtı, Güney tarafı, 4. satır; Bilge Kagan Yazıtı, Kuzey tarafı, 3. satır: Kurıgaru Yinçü Ögüzig keçe Temir Kapıgka tegi süledim.

${ }_{117}$ Bakınız, Köl İç Çor Yazıtı, Doğu tarafı, 4. satır: Yinçü Ögüzig keçe Temir Kapıgka Tezikke tegi süngüşdükde.
} 
Yula Köl: Biz bu su birikintisinin adına Şine Usu Yazıtında, 752 yılı olayları sırasında rastlamaktayız. Bildiğimiz gibi Moyun Çor Kagan'ın Türgiş ve Karluklarla da savaşları söz konusudur. Bunun için O, Cungarya bölgesindeki Yogarı Yarış Ovasına gitmeden önce herhalde ağırlıklarını Yula Köl'de bırakmış olmalıdır ki bu hususta kitabesinde; ebimin Ersegünte Yula Költe kotım $^{118}$ diyor. Ersegün ve Yula Köl'ün biz Cungarya'ya varmadan önceki bir yer olduğunu sanmaktayız ${ }^{119}$.

Şimdiye kadar otuzsekiz göl ve nehrin yerini tespite çalıştığımız gibi, tarihi önemleri üzerinde de kısaca durmaya özen gösterdik. Tabi ki bunların dışında da eski Türk yurtlarında binlerce akarsu ve göl mevcuttur. Türkçe belgelere akseden bu isimler değiştirilmeye kalkışılsa da sonsuza kadar onların tapusu olacaktır.

\section{Kaynakça}

Baytur, E., Şincan'daki Milletlerin Tarihi, Pekin 1991.

Bazin, L., "Notes de Toponymie Turque Ancienne", Acta Orientalia, 36/1-3, Budapest 1982.

Chavannes, E., Documents sur les Tou-Kiue [Turcs] Occidentaux, Petersburg 1903.

Deguignes, J.M., Hunların, Türklerin, Moğolların ve daha sair Tatarların Tarih-î Umumisi, C. II, İstanbul 1924.

Giraud, R., L'Empire des Turcs Celestes, Paris 1960, s.178-179; L.N.Gumilev, Hazar Çevresinde Bin Yıl, Çev. A.Batur, İstanbul 2001.

Gökyay, O.Ş., Dedem Korkudun Kitabı, İstanbul 1973.

Gömeç, S., “Umay Meselesi”, Türk Kültürü,, Sayı 318, Ankara 1989.

Gömeç, S., "Drevnyaya Religiya Tyurok", Şamanizm Kak Religiya: Genezis, Rekonstruktsiya, Traditsii. Tezisı Dokladov Mejdunarodnoy Nauçnoy Konferentsii, 15-22 avgusta 1992 g. Yakutsk 1992.

Gömeç, S., "Kök Türkçe Kaynaklarda Geçen Bayırkular", DTCF. Tarih Araştırmaları Dergisi, 16/26, Ankara 1994.

Gömeç, S., "Kök Türkçe Kaynaklarda geçen Boy ve Kavim Adları: Azlar", Belleten, 58/221, Ankara 1994.

Gömeç, S., "Kök Türkçe Kaynaklarda Geçen Boy ve Kavimler Üzerine: Çikler", Türk Kültürü,, 32/370, Ankara 1994.

${ }^{118}$ Bakınız, Şine Usu Yazıtı, Güney tarafı, 6. satır: Evimi Ersegün'deki Yula Köl'de bıraktım.

${ }^{119}$ Gömeç, "Şine-Usu Yazıtında...", s.432. 
Gömeç, S., "Terhin Yazıtının Tarihi Açıdan Değerlendirilmesi”, DTCF. Tarih Araştırmaları Dergisi, 27/28, Ankara 1996.

Gömeç, S., "Bögü Kagan'ın Yazıtı: Tez II”, Türk Dünyası Tarih Dergisi, Sayı 124, İstanbul 1997.

Gömeç, S., Kök Türk Tarihi, 2. baskı, Ankara 1999.

Gömeç, S., Uygur Türkleri Tarihi ve Külttürü, 2. bask1, Ankara 2000.

Gömeç, S., "Kök Türkçe Yazitlarda Geçen Yer Adları", Türk Kültürü, 34/453, Ankara 2001.

Gömeç, S., “Orkun”, Orkun, Say1 46, İstanbul 2001.

Gömeç, S., "Şine-Usu Yazıtı'nda Geçen Yer Adları Üzerine”, Belleten, LXIV/240, Ankara 2001.

Gömeç, S., "Türk Tarihinin Kahramanları: 13- Baz Kagan”, Orkun, Sayı 64, İstanbul 2003.

Gömeç, S., Türk Kültürünün Ana Hatları, Ankara 2006.

Klyaştornıy, S.G., "Terhinskaya Nadpis”, Sovyetskaya Tyurkologiya, No 3, Bakû 1980.

Orkun, H.N., Eski Türk Yazıtları, C. I, İstanbul 1938 .

Potapov, L.P., "O Narode Bökliyskoy Stepi”, Tyurkologiçeskiye Issledovaniya, Moskova-Leningrad 1963.

Ramstedt, G.J., "Zwei Uigurische Runeninschriften in der Nord-Mongolei”, Journal de la Sociètè Finno-Ougrienne, 30, Helsinki 1913/18. 